\title{
Design Approaches to Ecological Restoration
}

Nina-Marie E. Lister, Special Editor

Paul Beier, Special Editor

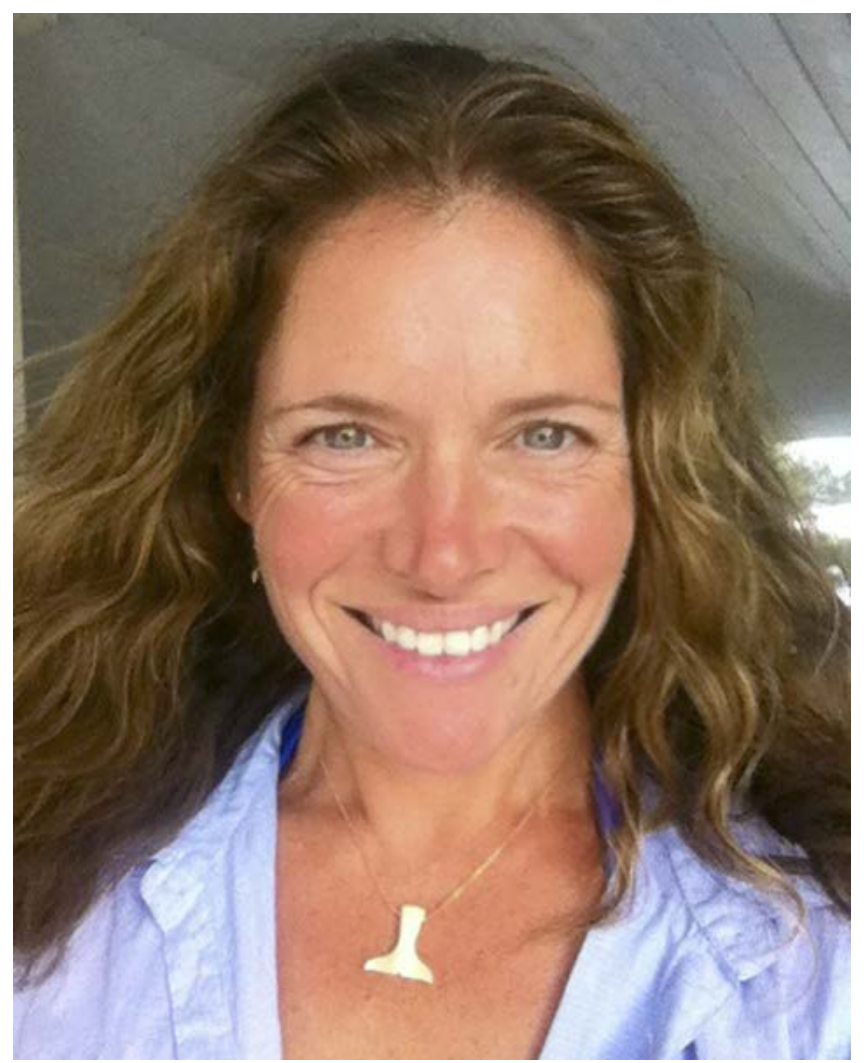

Nina-Marie E. Lister

Special Editor

Nina-Marie Lister, MCIP, RPP, is Associate Professor of Urban \& Regional Planning at Ryerson University in Toronto, Canada, and Visiting Associate Professor of Landscape Architecture at Harvard University, Graduate School of Design. She was the Professional Advisor to the ARC International Design Competition. Her teaching, published research, and practice are focused in ecological design and environmental planning. She is the founding principal of plandform, a creative studio practice exploring the relationship between landscape, ecology, and urbanism.

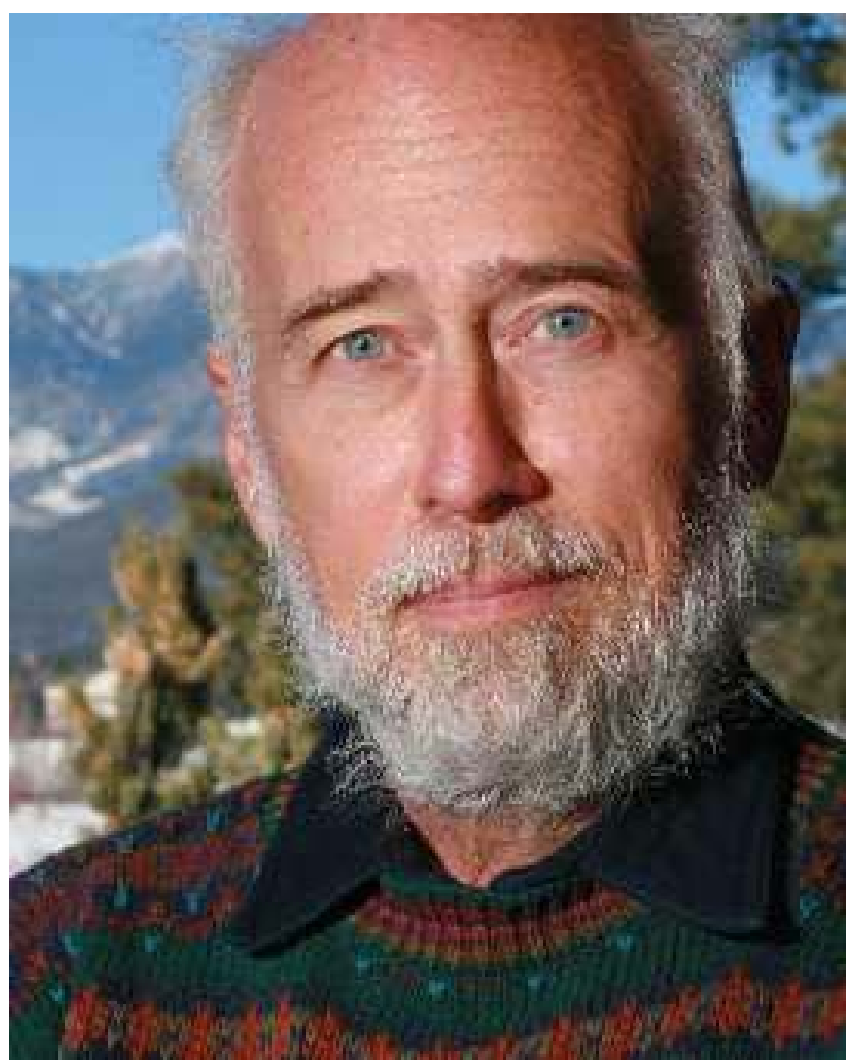

\section{Paul Beier Special Editor}

Paul Beier is a professor of conservation biology and wildlife ecology at Northern Arizona University. His 1988-1992 study of cougars documented that young cougars find and use habitat corridors to maintain gene flow among mountain ranges in urbanizing southern California. He was a lead author of the Wildlife Corridors initiative that was unanimously adopted by the Western Governors' Association in 2008. He co-authored 2 statewide maps of wildlife corridors, namely Arizona Wildlife Linkage Assessment (2006) and California Essential Habitat Connectivity (2010), and he has developed detailed corridor conservation plans for over 50 linkages in California, Arizona, and Bhutan. 